\title{
Preliminary study on the assessment of visceral adipose tissue using dual-energy $x$ - ray absorptiometry in chronic obstructive pulmonary disease
}

Francesca De Blasio ${ }^{1,2^{*}}$, Erica P. A. Rutten ${ }^{1}$, Emiel F. M. Wouters ${ }^{1}$, Luca Scalfi', Francesco De Blasio ${ }^{3}$, Marco A. Akkermans ${ }^{1}$, Martijn A. Spruit ${ }^{1}$ and Frits M. E. Franssen ${ }^{1}$

\begin{abstract}
Background: Visceral adipose tissue (VAT) was shown to be increased in patients with chronic obstructive pulmonary disease (COPD) compared to control subjects with comparable body mass index (BMI). Our aim was to determine the relation of VAT by dual-energy $x$-ray absorptiometry (DEXA) in patients with COPD by disease severity, BMI, other indices of body composition and static lung volumes.

Methods: 294 COPD patients admitted for rehabilitation were studied. Lung function, static lung volumes and body composition (i.e. BMI, waist circumference, fat-free mass, fat mass and fat distribution between android and gynoid fat mass) were assessed before entering pulmonary rehabilitation. VAT was estimated within the android region by using DEXA. Patients were stratified for gender, BMI (cut-off of $25 \mathrm{~kg} / \mathrm{m}^{2}$ ) and GOLD stage. To assess the impact of VAT on lung volumes, patients were also stratified for VAT less and above $50^{\text {th }}$ percentile.

Results: Both male and female patients with more severe airflow limitation had significantly lower VAT values, but these differences disappeared after stratification for BMI. VAT was significantly and strongly correlated with other body composition parameters (all $p<0.001$ ). Patients with moderate to severe airflow limitation and lower VAT had increased static lung hyperinflation and lower diffusing capacity for carbon monoxide. Nevertheless, multivariate stepwise regression models including for BMl, age, gender and forced expiratory volume in $1 \mathrm{~s}\left(\mathrm{FEV}_{1}\right)$ as confounders did not confirm an independent role for VAT on static lung hyperinflation and diffusion capacity.

Conclusion: After stratification for BMI, VAT is comparable in moderate to very severe COPD patients. Furthermore, BMI and demographics, but not VAT, were independent predictors of static lung hyperinflation and diffusing capacity in COPD.
\end{abstract}

Keywords: Body composition, COPD, DEXA, Fat mass, Visceral adipose tissue

\section{Background}

Although defined by the presence of persistent airflow limitation [1], alterations in body weight and body composition contribute to disease severity in patients with chronic obstructive pulmonary disease (COPD). Indeed, low body mass index (BMI) $\left(<21 \mathrm{~kg} / \mathrm{m}^{2}\right)$ is related to poor exercise

\footnotetext{
* Correspondence: francesca.deblasio1989@gmail.com

'Department of Research and Education, CIRO, Horn, The Netherlands

2Department of Public Health, "Federico II" University of Naples Medical

School, Naples, Italy

Full list of author information is available at the end of the article
}

tolerance [2], low fat-free mass (FFM) [3] and co-morbid osteoporosis [4]. Furthermore, it is incorporated in the prognostic assessment of COPD [5]. Otherwise, high BMI $\left(\geq 30 \mathrm{~kg} / \mathrm{m}^{2}\right)$ is related to increased dyspnea [6], reduced weight-bearing exercise performance [7] and systemic inflammation in COPD. [3] At the same time, reductions in lung volumes have been consistently reported in obese COPD patients [8].

In addition to the discriminating role of BMI in the clinical phenotyping of COPD patients, alterations in body composition, i.e. the distribution between FFM and 
fat mass (FM), are common and have additional impact on the burden of disease. In more detail, visceral adipose tissue (VAT) is receiving increasing attention in COPD, since it was shown that elderly subjects with obstructive lung disease have increased visceral adipose area in comparison with control subjects with comparable BMI [9]. Also, there is increasing evidence for a role of VAT in the pathophysiology of systemic inflammation [10] and cardiovascular morbidity in COPD [10, 11]. Typically, VAT is assessed by computer tomography (CT) or magnetic resonance imaging (MRI), but these measurements are expensive, time-consuming and not widely available. Alternatively, dual-energy $x$-ray absorptiometry (DEXA) is a commonly used device with lower radiation dose, alternative to estimate body composition in COPD and was recently introduced as a validated method to quantify VAT $[12,13]$. However, no clinical studies investigating VAT with DEXA are available in COPD patients. Thus, associations between VAT assessed by this method and other traditional markers of body composition in COPD are currently unknown. Also, the impact of VAT per se on lung volumes has not been studied in COPD.

Therefore, the aims of the present study were: 1) to quantify the amount of VAT measured by DEXA in patients with COPD in relation to disease severity and BMI; 2) to explore the relationships between VAT and other indices of body composition and 3) to study the impact of VAT on static lung volumes. In the present study, we hypothesized that VAT does significantly and negatively influence static lung volumes and hyperinflation in patients with COPD.

\section{Methods}

\section{Patient selection}

Data were abstracted from the Integrated Knowledge System based on BioXM ${ }^{\mathrm{m}}$ (Biomax Informatics AG, Munich, Germany) of 294 patients with a primary diagnosis of COPD [post-bronchodilator forced expiratory volume in $1 \mathrm{~s}\left(\mathrm{FEV}_{1}\right) /$ forced vital capacity $(\mathrm{FVC})$ ratio of $\leqslant 0.70$ and post-bronchodilator $\mathrm{FEV}_{1}<80 \%$ predicted] who were evaluated during the initial assessment of a comprehensive pulmonary rehabilitation (PR) program at CIRO Horn (The Netherlands) between August 2014 and May 2015 [14]. Exclusion criteria were: a history of asthma, $\alpha 1$-antitrypsin deficiency, lung cancer, any previous lung surgery, instable inflammatory or endocrine diseases, acute myocardial infarction within the last 6 months, any known bone disease other than osteoporosis, treated malignant disease within the last 5 years and an exacerbation of COPD within the last 4 weeks. Ethical approval was not indicated because all of the tests were done as part of the routine initial assessment [14], and analyzed retrospectively. The Board of Directors of CIRO approved the use of de-identified patients' records.

\section{Lung function measurement}

As part of the routine 3-day initial assessment of integrated health status, all patients performed post-bronchodilator spirometry (Masterlab ${ }^{\circ}$ Jaeger, Würzburg, Germany). FEV $_{1}$ and FVC were assessed in accordance with the latest GOLD guidelines [1]. Inspiratory vital capacity (IVC) was assessed too. Plethysmographic lung volumes, such as Total Lung Capacity (TLC), Intra Thoracic Gas Volume (ITGV), Expiratory Reserve Volume (ERV) and Residual Volume (RV) were assessed. Inspiratory Capacity(IC)/TLC ratio [15] was calculated by dividing TLC - ITGV for TLC, and was used as a marker for hyperinflation (defined as an abnormal increase in the volume of air remaining in the lungs at the end of spontaneous expiration [16]). Diffusing capacity of the lung for carbon monoxide $\left(\mathrm{DL}_{\mathrm{CO}}\right)$ was measured using the single-breath method. All obtained values are expressed as percentages of the predicted value, by comparison with age and sex-specific reference values [17].

\section{Body composition}

Body height was measured to the nearest $0.5 \mathrm{~cm}$ with a wall-mounted stadiometer. Body weight was assessed to the nearest $0.1 \mathrm{~kg}$ using a weighing scale, and BMI was calculated as weight $/$ height ${ }^{2}$. A total body scan was performed by DEXA using a Lunar Prodigy ${ }^{\circ}$ system (GE Healthcare - enCORE v14, Madison, WI, USA). Subjects lay supine on the DEXA table with arms adequately separated from the trunk and were instructed to remain still throughout the scanning procedure. After analysis of the whole body scan, a quadrilateral box was manually drawn around the L1-L4 region of interest (abdomen) bounded inferiorly by the horizontal line identifying L4/ L5 vertebral space and superiorly by the horizontal line identifying the T12/L1 vertebral space. Scans were displayed with an adjustment of the gray scale, so that all of the soft tissue in the designated area was included. From the total body scan, body composition was assessed: bone mineral content (BMC), lean mass (LM), FFM (LM plus BMC). FFMI was calculated by dividing FFM by height ${ }^{2}$, and FM by subtracting FFM from total weight. The base of the android region (Fig. 1a - shown in blue) sits immediately above the pelvis and is in height equal to $20 \%$ of the distance from the pelvis to the chin. The android and gynoid (Fig. 1a - shown in red) regions are separated by a distance equal to 1.5 times the height of the android region, while the height of the gynoid region is double that of the android one. VAT was estimated within the android region [12] (Fig. 1 b number 1 ).

\section{Statistical Analysis}

Values are reported as means \pm SD with the exception of continuous variables, presented as median and interquartile range (IQR). In order to quantify the amount of 


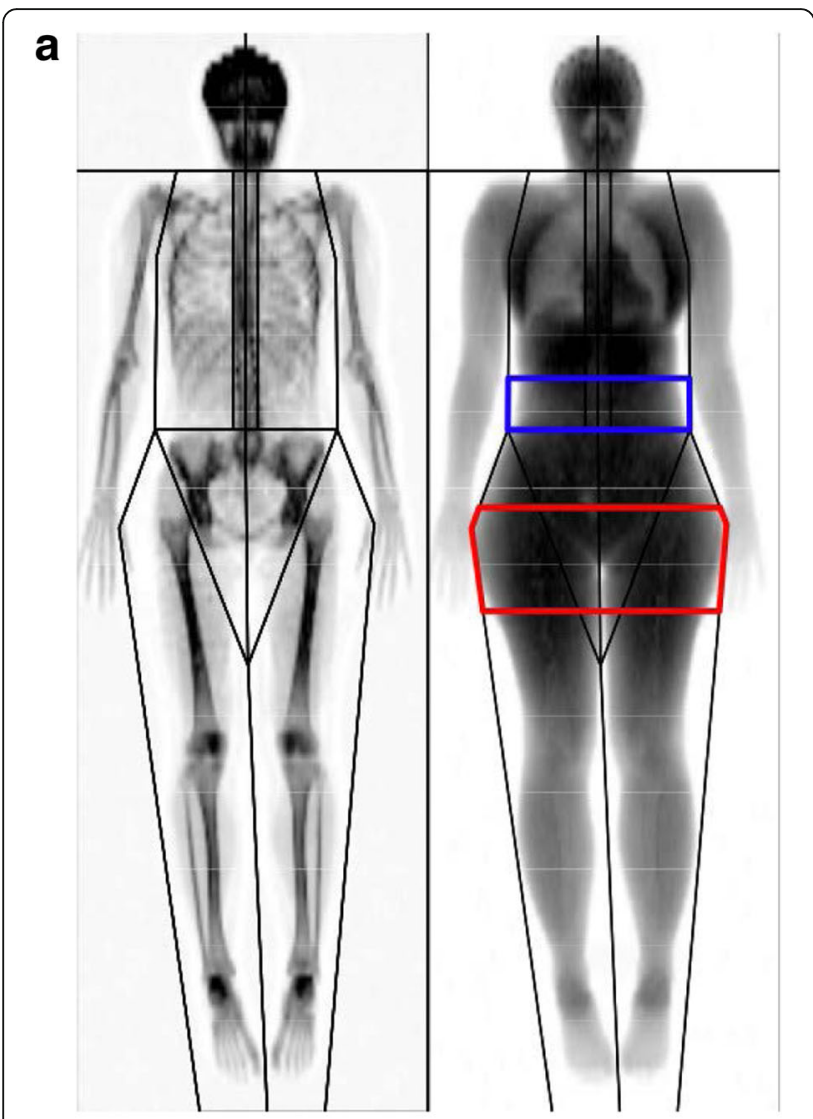

b

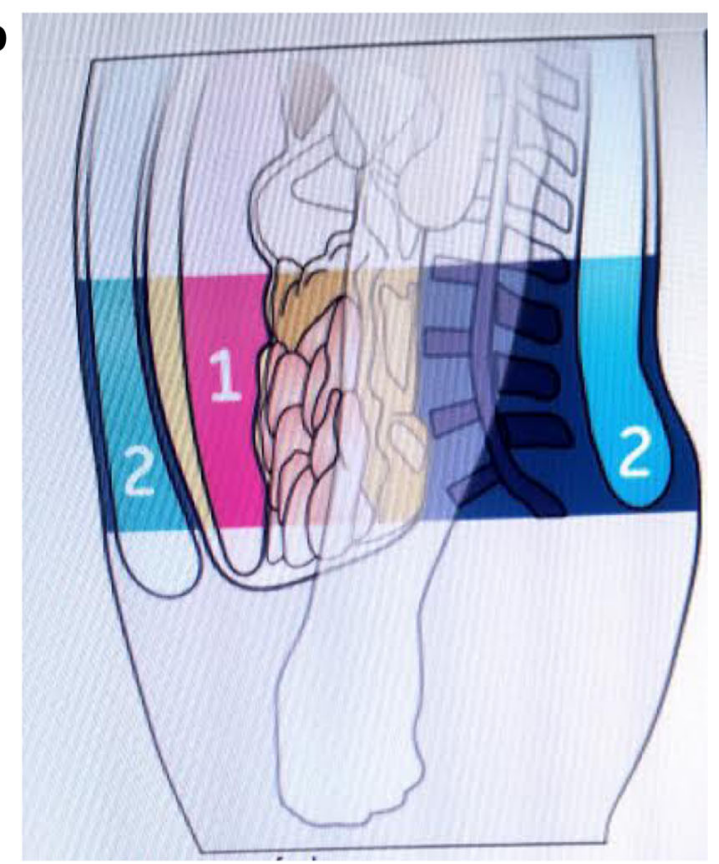

Fig. 1 a A model of total body DEXA scan. The android region is highlighted in blue and the gynoid region is highlighted in red (refer to text for further explanations). b Representation of visceral adipose tissue (1) and subcutaneous adipose tissue (2) within the android region
VAT in relation to disease severity, patients were stratified for gender, BMI (cut-off of $25 \mathrm{~kg} / \mathrm{m}^{2}$ ) and GOLD stages (I + II, III, IV). Since the proportion of patients with mild airflow limitation referred for PR is limited [18], these patients were grouped with those with moderate airflow limitation. Furthermore, in order to study the impact of VAT on lung volumes, both men and women were divided in two subgroups according to VAT $50^{\text {th }}$ percentile (2183.0 $\mathrm{g}$ for men and $912.5 \mathrm{~g}$ for women).

Statistical analysis was performed using SPSS version 20.0. Comparisons across GOLD stages were performed using ANOVA with post-hoc Tukey-Kramer tests for multiple comparisons. Subsequently, multivariate stepwise linear regression analysis was performed to investigate a relationship between VAT and selected indices of lung hyperinflation. A $p<0.05$ was considered significant in all analyses.

\section{Results}

\section{Subjects characteristics}

Patients were characterized by moderate to very severe airflow obstruction (GOLD I/II, $44.9 \%$; GOLD III, $38.1 \%$; GOLD IV, $17.0 \%$ ). 154 (52.4 \%) were men (median age 67 years, IQR 13 years; median BMI $26.9 \mathrm{~kg} /$ $\mathrm{m}^{2}$, IQR $8.6 \mathrm{~kg} / \mathrm{m}^{2}$ ) and $140(47.6 \%)$ were women (median age 61 years, IQR 13 years; median BMI $25.3 \mathrm{~kg} /$ $\mathrm{m}^{2}$, IQR $\left.8,1 \mathrm{~kg} / \mathrm{m}^{2}\right)$. The median number of pack/ years smoked was 40 (IQR 24), $30.3 \%$ of patients were current smokers and $63.6 \%$ of patients were former smokers. $25.5 \%$ of patients used long-term oxygen therapy.

\section{VAT across GOLD stages}

The amount of VAT separated for men and women is shown in Fig. 2a. In each GOLD subgroup VAT was greater in men than in women (in all GOLD stages: $p<0.001$ ). Furthermore, patients with more severe airflow obstruction had significantly lower values of VAT, both in men (GOLD I/II: $2501.1 \mathrm{~g} \pm 1141.7 \mathrm{~g}$; GOLD III: $2246.4 \mathrm{~g} \pm 1488.5 \mathrm{~g}$; GOLD IV: $1697.2 \mathrm{~g} \pm 1350.1 \mathrm{~g}$, $p=0.031$ ) and women (GOLD I/II: $1259.7 \mathrm{~g} \pm 938.0 \mathrm{~g}$; GOLD III: $1160.0 \pm 929.8$ g, GOLD IV: $653.0 \pm 442.8$ g, $p=0.015$ ). Figure $2 \mathrm{~B}$ shows the amount of VAT in the three different GOLD subgroups after stratification for BMI: as it could be expected, patients with a BMI $\geq$ $25 \mathrm{~kg} / \mathrm{m}^{2}$ had consistently higher values of VAT, compared with those with a BMI $<25 \mathrm{~kg} / \mathrm{m}^{2}(p<0.001)$, both in men and women. After stratification for gender and BMI, differences in VAT across the three GOLD subgroups disappeared (Fig. 2b).

\section{Relationships of VAT with other indices of total and central adiposity}

The amount of VAT was significantly and strongly correlated with BMI, waist circumference, FM, FMI, android fat 


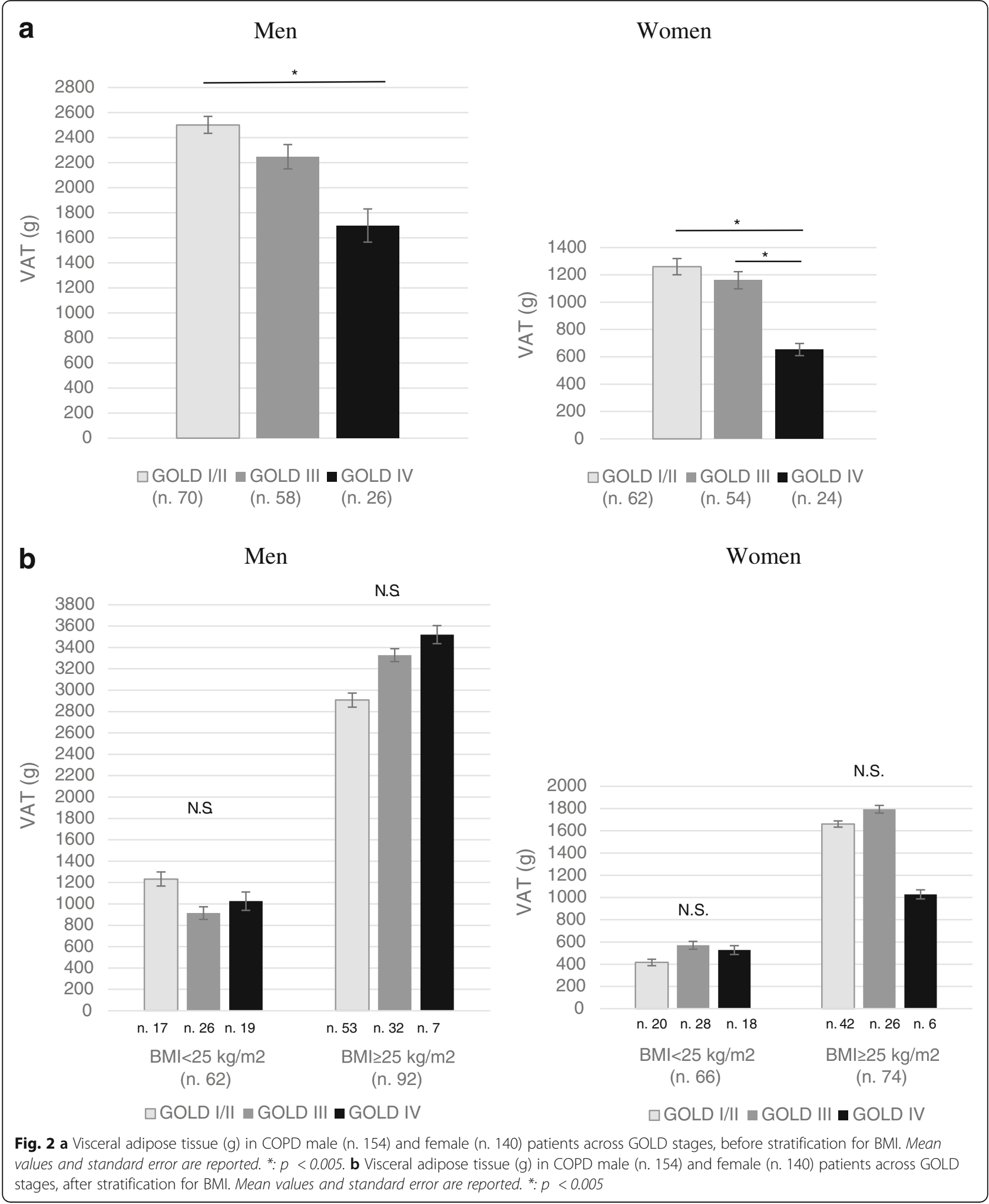

mass and gynoid fat mass (Fig. 3 a-f). The strength of correlations was higher in male than in female patients. Android fat mass was the most strongly correlated with
VAT $\left(r^{2}=0.919\right.$ in men; $r^{2}=0.857$ in women), followed by waist circumference $\left(r^{2}=0.831\right.$ in men; $r^{2}=0.757$ in women), FM $\left(r^{2}=0.858\right.$ in men; $r^{2}=0.694$ in women $)$, 

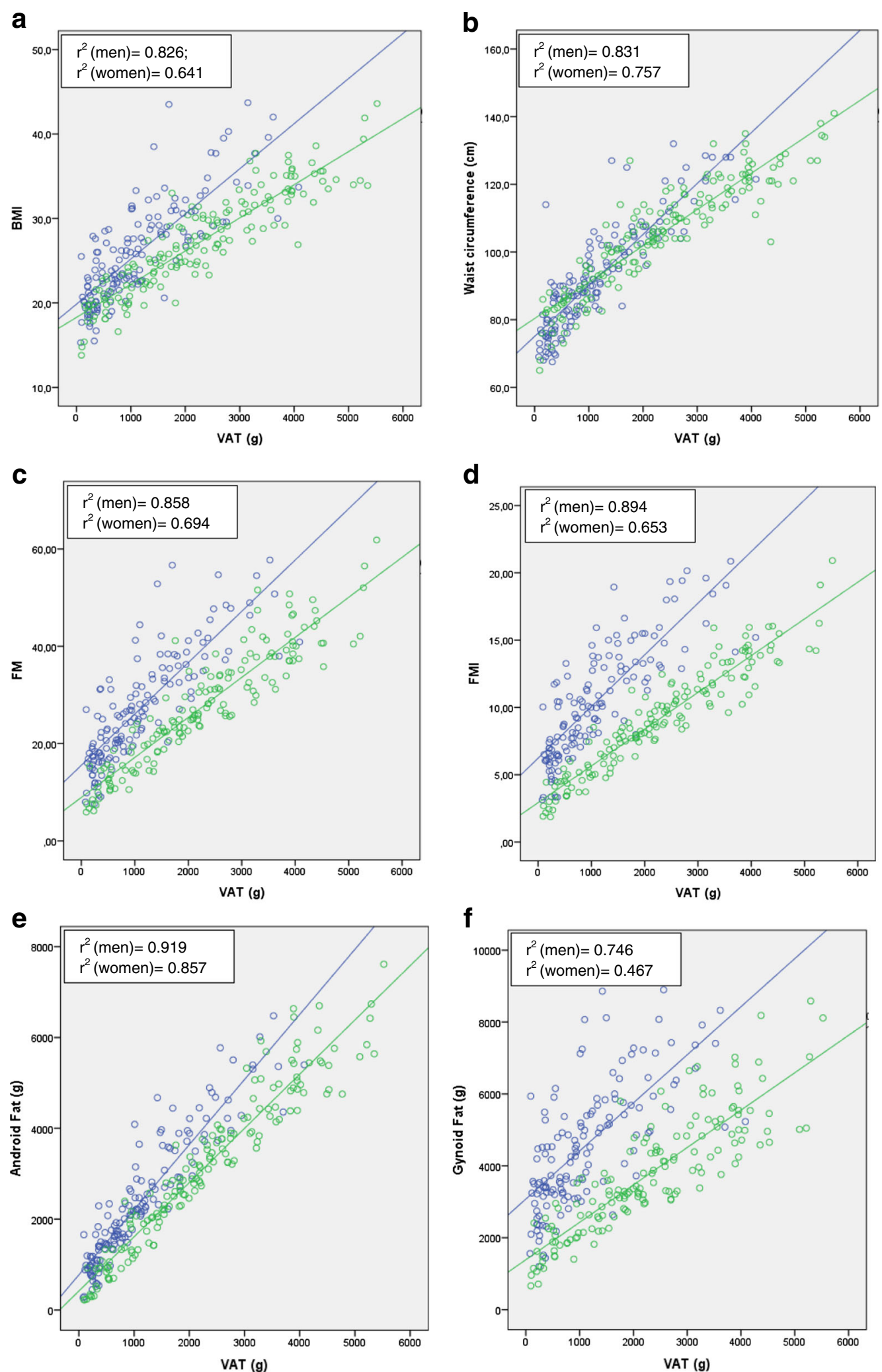

Fig. 3 Correlation plots of VAT with BMI (a), waist circumference (b), FM (c), FMI (d), android fat mass (e) and gynoid fat mass (f). $P$ were $<0.001$ for each correlation, in both genders (o (Blue) = men; o (Green) = women) 
FMI $\left(r^{2}=0.894\right.$ in men; $r^{2}=0.653$ in women), BMI $\left(r^{2}=0.826\right.$ in men; $r^{2}=0.641$ in women $)$ and gynoid fat $\left(r^{2}=0.746\right.$ in men; $r^{2}=0.467$ in women $)$.

\section{Impact of VAT on lung volumes}

Besides disease severity, patients were stratified for VAT less and above the $50^{\text {th }}$ percentile. Patients with moderate to severe airflow limitation and lower VAT levels had increased ITGV and ERV and reduced IC/TLC (Table 1) compared to those with higher VAT levels. There was no significant difference for $\mathrm{FEV}_{1}$ (\% pred), $\mathrm{FEV}_{1} / \mathrm{FVC}$ (\%) or IVC (\% pred), or for lung volumes in GOLD IV patients.

The same trend was observed in both genders, although it was less pronounced in female than in male patients (data not shown). $\mathrm{DL}_{\mathrm{CO}}$ was significantly increased in patients with greater VAT in all GOLD categories $(p=0.002$ in GOLD I + II; $p=0.003$ in GOLD III; $p=0.015$ in GOLD IV). The same finding was true when considering male and female patients separately.

\section{Determinants of hyperinflation}

In order to investigate whether VAT itself is a predictor of lung hyperinflation, independently from BMI, age, gender and $\mathrm{FEV}_{1}(\mathrm{~L})$, stepwise regression was performed and results are shown in Table 2. Considering IC/TLC (\%) as dependent variable (and $\mathrm{FEV}_{1}$ as the best predictor), the $\mathrm{r}^{2}$ of the regression model was 0.701 . Only $\mathrm{FEV}_{1}(\mathrm{~L}), \mathrm{BMI}$, age and gender are included in the final equation and the multiple regression was significant $(p<0.001)$. VAT was excluded from the model.

Similar results were obtained when choosing ITGV (L) as dependent variable (Table 3). Only BMI, gender, $\mathrm{FEV}_{1}$ $(\mathrm{L})$ and age were significant determinants, the $\mathrm{r}^{2}$ was 0.465 and the regression was significant $(p<0.001)$. VAT was again excluded from the model.

Concerning diffusing capacity, stepwise regression results showed that $\mathrm{FEV}_{1}(\mathrm{~L})$, age, gender and BMI were significant determinants of $\mathrm{DL}_{\mathrm{CO}}(\mathrm{L})$ in the way that younger male patients and patients with higher BMI and higher $\mathrm{FEV}_{1}(\mathrm{~L})$, have also higher $\mathrm{DL}_{\mathrm{CO}}$ values (Table 4). Nevertheless, VAT was again excluded from the model. The $r^{2}$ of the regression model was high (0.532), and the regression was significant $(p<0.001)$.

\section{Discussion}

The present study reported several novelties regarding the research concerning the involvement of the adipose tissue in the pathology of COPD. First, it showed that VAT is comparable across GOLD stages for airflow limitation if BMI is taken into account. Second, traditional markers of total and central adiposity correlated very well with VAT assessed by DEXA. Third, VAT is not an independent predictor of static lung hyperinflation in COPD, while demographics and BMI are.

Table 1 General and clinical parameters in 294 COPD patients stratified for GOLD stages and divided in two groups, based on VAT $50^{\text {th }}$ percentile $(2183 \mathrm{~g}$ for men; $912.5 \mathrm{~g}$ for women)

\begin{tabular}{|c|c|c|c|c|c|c|c|c|c|}
\hline & \multicolumn{3}{|c|}{ GOLD I + II (n. 132) } & \multicolumn{3}{|l|}{ GOLD III (n. 112) } & \multicolumn{3}{|l|}{ GOLD IV (n. 50) } \\
\hline & $\overline{V A T}<50^{\text {th }}$ & VAT $>50^{\text {th }}$ & $P$ & VAT $<50^{\text {th }}$ & VAT $>50^{\text {th }}$ & $P$ & $\overline{V A T}<50^{\text {th }}$ & VAT $>50^{\text {th }}$ & $P$ \\
\hline Age (years) & $65.3 \pm 10.9$ & $64.9 \pm 9.2$ & 0.856 & $65.1 \pm 10.4$ & $65.7 \pm 6.8$ & 0.697 & $59.6 \pm 7.5$ & $59,1 \pm 10.5$ & 0.868 \\
\hline $\mathrm{BMI}\left(\mathrm{kg} / \mathrm{m}^{2}\right)$ & $24.0 \pm 3.5$ & $31.9 \pm 4.4$ & $<0.001$ & $21.6 \pm 2.9$ & $30.5 \pm 4.8$ & $<0.001$ & $20.7 \pm 3.4$ & $28.1 \pm 4.5$ & $<0.001$ \\
\hline FFMI $\left(\mathrm{kg} / \mathrm{m}^{2}\right)$ & $16.7 \pm 2.4$ & $18.7 \pm 2.6$ & $<0.001$ & $15.5 \pm 1.7$ & $17.9 \pm 2.5$ & $<0.001$ & $14.6 \pm 1.4$ & $16.9 \pm 2$ & $<0.001$ \\
\hline $\mathrm{FMl}\left(\mathrm{kg} / \mathrm{m}^{2}\right)$ & $7.5 \pm 2.0$ & $13.2 \pm 3.0$ & $<0.001$ & $6.4 \pm 2.4$ & $12.7 \pm 3.1$ & $<0.001$ & $6.2 \pm 2.6$ & $11.3 \pm 2.9$ & $<0.001$ \\
\hline Gynoid Fat (g) & $3322.2 \pm 1005.5$ & $5517.6 \pm 1314.4$ & $<0.001$ & $2770.4 \pm 1031.5$ & $5148.4 \pm 1572.9$ & $<0.001$ & $2810.2 \pm 1251.9$ & $4737.4 \pm 1397.2$ & $<0.001$ \\
\hline Android Fat (g) & $1797.3 \pm 769.0$ & $4120.8 \pm 1110.6$ & $<0.001$ & $1428,9 \pm 736.2$ & $3997.5 \pm 1274.8$ & $<0.001$ & $1336.6 \pm 760.1$ & $3641.8 \pm 1513.6$ & $<0.001$ \\
\hline $\mathrm{FEV}_{1}$ (\% pred) & $70.6 \pm 20.6$ & $68.9 \pm 13.5$ & 0.572 & $38.5 \pm 5.5$ & $39.6 \pm 5.7$ & 0.306 & $23.4 \pm 5.0$ & $25.2 \pm 3.1$ & 0.181 \\
\hline $\mathrm{FEV}_{1} / \mathrm{FVC}(\%)$ & $46.8 \pm 11.3$ & $49.4 \pm 9.6$ & 0.160 & $31.5 \pm 6.7$ & $33.4 \pm 7.4$ & 0.157 & $22.9 \pm 4.4$ & $26.2 \pm 7.3$ & 0.050 \\
\hline IVC (\% pred) & $115.9 \pm 19.5$ & $108.1 \pm 18.7$ & 0.021 & $96.3 \pm 17.0$ & $93.0 \pm 15.9$ & 0.289 & $79.8 \pm 15.4$ & $78.4 \pm 15.0$ & 0.750 \\
\hline ITGV (\% pred) & $132.9 \pm 27.6$ & $112.5 \pm 21.9$ & $<0.001$ & $163.6 \pm 33.1$ & $146.0 \pm 27.1$ & 0.003 & $193.4 \pm 35.1$ & $174.6 \pm 37.6$ & 0.090 \\
\hline ERV (\% pred) & $132.6 \pm 46.4$ & $106.9 \pm 44.9$ & 0.002 & $130.6 \pm 40.1$ & $112.2 \pm 35.1$ & 0.012 & $106.4 \pm 29.8$ & $90.4 \pm 35.9$ & 0.103 \\
\hline RV (\% pred) & $134.0 \pm 33.7$ & $116.1 \pm 26.9$ & 0.001 & $178.3 \pm 40.3$ & $159.3 \pm 32.6$ & 0.008 & $234.5 \pm 61.8$ & $212.9 \pm 48.8$ & 0.226 \\
\hline IC/TLC (\%) & $37.9 \pm 8.2$ & $42.6 \pm 7.2$ & 0.001 & $26.6 \pm 7.7$ & $30.2 \pm 6.5$ & 0.008 & $20.3 \pm 5.4$ & $24.0 \pm 5.2$ & 0.027 \\
\hline DLCO (\% predicted) & $54.8 \pm 15.9$ & $65.5 \pm 22.6$ & 0.002 & $42.7 \pm 12.9$ & $50.6 \pm 12.5$ & 0.003 & $33.6 \pm 13.1$ & $45.1 \pm 16.4$ & 0.015 \\
\hline
\end{tabular}

Values reported as mean \pm standard deviation

$B M I$ body mass index, FFM fat-free mass index, FMI fat mass index, FEV forced expiratory volume in $1 \mathrm{~s}, F V C$ forced vital capacity, IVC max inspiratory vital capacity, ITGV intra-thoracic gas volume, ERV expiratory reserve volume, RV residual volume, IC inspiratory capacity, TLC total lung capacity, DLCO diffusing capacity of the lung for carbon monoxide

Statistically significant $p$ are indicated in bold characters 
Table 2 Multivariate stepwise regression with IC/TLC (\%) as dependent variable

\begin{tabular}{lll}
\hline Model & \multicolumn{2}{l}{$\begin{array}{l}\text { Standardized Coefficients } \\
\text { Beta }\end{array}$} \\
\hline (Constant) & & Sig. \\
FEV $_{1}$ (L) &, 710 &, 000 \\
BMl &, 289 &, 000 \\
Age &,- 091 &, 007 \\
Gender* &,- 092 &, 010
\end{tabular}

Independent variables: VAT, BMI, age, gender and FEV Adjusted $\mathrm{R}^{2}=0.697$. VAT was excluded from the model * gender $=0$ for women; $=1$ for men

\section{VAT in COPD}

Furutate et al. [19] investigated VAT in patients with COPD using CT. They observed that VAT was higher in COPD compared to controls with comparable BMI, and that VAT tended to increase with COPD progression, although not all differences were statistically significant. In addition, the authors found that, in patients with severe emphysema, VAT was retained despite the absence of obesity. In the same study, BMI, waist circumference, FFMI, FMI and SAT were shown to decrease with increasing emphysematous severity. Besides the fact that we did not relate VAT to emphysema severity, the differences in ethnicity (Furutate included a Japanese sample, the present study population were all caucasians) between studies makes comparison difficult, but our results indicates that VAT is comparable across GOLD stages, after stratification for BMI.

\section{Assessment of VAT in COPD}

Several methods can be used for measuring VAT. The most commonly used imaging technique is abdominal $\mathrm{CT}$, one of the current gold standards for quantifying VAT [20-24]. However, because of the radiation dose involved, the high costs and the heavily utilized clinical equipment requirement, $\mathrm{CT}$ is not optimal as screening method for VAT. MRI has also been used for VAT

Table 3 Multivariate stepwise regression with ITGV (L) as dependent variable

\begin{tabular}{|c|c|c|}
\hline \multirow[t]{2}{*}{ Model } & Standardized Coefficients & \multirow[t]{2}{*}{ Sig. } \\
\hline & Beta & \\
\hline (Constant) & &, 000 \\
\hline BMI &,- 385 &, 000 \\
\hline Gender* &, 505 &, 000 \\
\hline $\mathrm{FEV}_{1}(\mathrm{~L})$ &,- 391 &, 000 \\
\hline Age &,- 133 & 003 \\
\hline
\end{tabular}

Independent variables: $\mathrm{VAT}, \mathrm{BMI}$, age, gender and $\mathrm{FEV}_{1}$ Adjusted $R^{2}=0.458$. VAT was excluded from the model ${ }^{*}$ gender $=0$ for women; $=1$ for men
Table 4 Multivariate stepwise regression with $\mathrm{DL}_{\mathrm{CO}}(\mathrm{L})$ as dependent variable

\begin{tabular}{lll}
\hline Model & $\begin{array}{l}\text { Standardized Coefficients } \\
\text { Beta }\end{array}$ & Sig. \\
\hline (Constant) & & $<0.001$ \\
FEV $_{1}(\mathrm{~L})$ & 0.428 & \\
Age & -0.232 & $<0.001$ \\
Gender & 0.239 & $<0.001$ \\
BMl & 0.302 & $<0.001$ \\
\hline
\end{tabular}

Independent variables: VAT, BMI, age, gender and FEV

Adjusted $R^{2}=0.525$. VAT was excluded from the model

*gender $=0$ for women; $=1$ for men

measurement $[25,26]$. It avoids the radiation dose involved with CT measurements but still requires an expensive and time-consuming procedure as well as heavily utilized clinical equipment. DEXA is another suitable clinical reference method for the assessment of body composition. It measures the differential attenuation of two different energy level $\mathrm{x}$-rays as they pass through the body and subdivides soft tissue into bone, lean and fat compartments. New software was recently proposed to quantify VAT in the android region by DEXA [12,13], with several advantage relative to CT and MRI, such as lower costs, lower $\mathrm{x}$-ray exposure and short-scanning time [27-30].

\section{Correlates of VAT}

To date, no data are available on relationships between VAT measured by DEXA and other indices of body composition in COPD patients. In the present study we find a strong and significant correlation of VAT with BMI, waist circumference, FM, FMI as well as android and gynoid fat mass, in both genders but more strongly in males (likely due to their higher amount of VAT compared with females). As reported by Kaul et al., DEXA is a valid tool for quantification of VAT and other adipose tissue regions in the clinical setting [12], but more studies are needed in COPD in order to validate this method against CT, which is one of the current gold standards for quantifying VAT.

\section{Hyperinflation in COPD}

To the best of the authors' knowledge, this study is the first that carefully evaluated VAT by DEXA in relation to static lung volumes in a large group of patients with moderate to very severe COPD. O'Donnell et al. [31] examined the relationship between increasing BMI and plethysmographic lung volumes in a population with airflow obstruction. It was shown that lung hyperinflation decreased exponentially with increasing BMI. However, the potential impact of fat distribution on lung volumes was not investigated. In the present study, patients with greater VAT seemed to have lower ITGV, ERV, RV and 
higher IC/TLC and DL $\mathrm{CO}$ without a difference in $\mathrm{FEV}_{1}$, $\mathrm{FEV}_{1} / \mathrm{FVC}$ or IVC in most GOLD stages (and most pronounced in early GOLD stage). This finding appears to confirm that the major effect of obesity is on lung volumes, with no direct effect on airway obstruction [32]. The results of the multiple stepwise regression analysis confirmed a predicted role of $\mathrm{FEV}_{1}, \mathrm{BMI}$, gender and age on lung hyperinflation but no independent role of VAT for any of the lung volume parameters. This finding is somewhat surprising, since VAT is located in the abdominal region below the respiratory compartment. Future studies have to seek out what parameters of obesity are related to lung hyperinflation. Probably SAT in the abdominal and thoracic region could be worth considering.

In health, increasing BMI is known to be associated with increasing diffusing capacity, possibly reflecting the increased pulmonary blood volume in obesity [33, 34]. In the current study, a relationship was confirmed between increasing BMI and $\mathrm{DL}_{\mathrm{CO}}$ in COPD patients. Nevertheless, no significant predictive role of VAT on $\mathrm{DL}_{\mathrm{CO}}$ was found.

\section{Limitations and strengths of the study}

Various limitations of the study have to be considered. Firstly, there was no age-matched healthy control group included in the present study. Previous studies, however, already suggested that COPD patients have increased VAT by CT scan compared to matched controls. Secondly, no gold standard reference method (such as $\mathrm{CT}$ ) was available and future studies need to validate the DEXA device for VAT. As mentioned in the introduction however, this was not the aim of the present study. Beyond these limitations, the major strength of this study was that it is the first study, which used DEXA in order to measure VAT in COPD patients. Additionally, a large population with moderate to very severe disease and careful clinical characterization was enrolled in the study.

\section{Conclusions}

In conclusion, after stratification for BMI, VAT is comparable across GOLD stages in moderate to very severe COPD patients. VAT measured by DEXA is strongly correlated to other traditional and most commonly used body composition parameters, such as BMI, waist circumference as well as android and gynoid fat mass. BMI and demographics, but not VAT, were independent predictors of static lung hyperinflation and diffusing capacity in COPD.

\section{Clinical implications}

VAT is now recognized as a risk factor for metabolic syndrome, diabetes, and cardiovascular disease [35-41]. Furthermore, since cardiovascular disease is one of the main comorbidities in COPD, together with type II diabetes, skeletal muscle dysfunction and osteoporosis [3], VAT is receiving increasing attention in clinical assessment of COPD patients.

DEXA provides lots of useful information in clinical practice. Not only is it the gold standard method for evaluating bone mineral density and discriminate patients with and without osteoporosis, but it is also a useful method for the assessment of other clinically relevant body composition parameters, among which VAT.

\begin{abstract}
Abbreviation
$B M I$, body mass index; COPD, chronic obstructive pulmonary disease; $C T$, computed tomography; DEXA, dual-energy $x$-ray absorptiometry; DLCO, diffusing capacity of the lung for carbon monoxide; ERV, expiratory reserve volume; $\mathrm{EEV}_{1}$, forced expiratory volume in $1 \mathrm{~s}$; FFM, fat-free mass; FFMl, fat-free mass index; FM, fat mass; FVC, forced vital capacity; GOLD, global initiative for chronic obstructive lung disease; IC, inspiratory capacity; IQR, interquartile range; ITGV, intra thoracic gas volume; IVC, inspiratory vital capacity; MRI, magnetic resonance imaging; PR, pulmonary rehabilitation; RV, residual volume; SAT, subcutaneous adipose tissue; TLC, total lung capacity; VAT, visceral adipose tissue.
\end{abstract}

\section{Acknowledgement}

We acknowledge all the staff of Department of Research and Education, CIRO for contribution towards the study by making acquisition of data.

\section{Funding}

The work was carried out using inter-departmental support with no extramural fund support.

\section{Availability of data and supporting materials section}

We do not wish to share our data as they were collected as part of routine clinical care and we anonymously analysed these.

\section{Authors' contribution}

All authors played a role in the content and writing of the manuscript. The contribution of the authors to the manuscript is as follows: FLMdB: study design, analysing data, drafting the manuscript, primary responsibility of the final content; EFMW, LS, FdB: reviewing the manuscript; MA: supervised the pulmonary function laboratory and provided the database; EPAR and MAS: providing statistical advice and supervising the analysis and reviewing the manuscript; FMEF: study design, drafting the manuscript and primary responsibility of the final content, reviewing the manuscript.

\section{Competing interests}

The authors declare that they have no competing interests.

\section{Consent for publication}

This manuscript does not contain any individual persons data, thus the request of a consent for publication is not applicable.

\section{Ethics approval and consent to participate}

Ethics approval was not indicated because all of the tests were done as part of the routine initial assessment, and analyzed retrospectively. The Board of Directors of CIRO approved the use of de-identified patients' records.

\section{Author details}

'Department of Research and Education, CIRO, Horn, The Netherlands. ${ }^{2}$ Department of Public Health, "Federico II" University of Naples Medical School, Naples, Italy. ${ }^{3}$ Respiratory Medicine and Pulmonary Rehabilitation Section, Clinic Center, Private Hospital, Naples, Italy.

Received: 31 May 2016 Accepted: 14 July 2016

Published online: 04 October 2016

References

1. Vestbo J, Hurd SS, Agusti AG, Jones PW, Vogelmeier C, Anzueto A, et al. Global strategy for the diagnosis, management, and prevention of chronic obstructive pulmonary disease: GOLD executive summary. Am J Respir Crit Care Med. 2013;187:347-65. 
2. Schols AM, Soeters PB, Dingemans AM, Mostert R, Frantzen PJ, Wouters EF. Prevalence and characteristics of nutritional depletion in patients with stable COPD eligible for pulmonary rehabilitation. Am Rev Respir Dis. 1993;147:1151-6.

3. Vanfleteren LE, Spruit MA, Groenen M, Gaffron S, van Empel VP, Bruijnzeel $\mathrm{PL}$, et al. Clusters of comorbidities based on validated objective measurements and systemic inflammation in patients with chronic obstructive pulmonary disease. Am J Respir Crit Care Med. 2013;187:728-35.

4. Vrieze A, de Greef MH, Wijkstra PJ, Wempe JB. Low bone mineral density in COPD patients related to worse lung function, low weight and decreased fat-free mass. Osteoporos Int. 2007;18:1197-202.

5. Celli BR, Cote CG, Marin JM, Casanova C, Montes De Oca M, Mendez RA, et al. The body-mass index, airflow obstruction, dyspnea, and exercise capacity index in chronic obstructive pulmonary disease. N Engl J Med. 2004;350: 1005-12.

6. Cecere LM, Littman AJ, Slatore CG, Udris EM, Bryson CL, Boyko EJ, et al. Obesity and COPD: associated symptoms, health-related quality of life, and medication use. 2011;COPD 8:275-84.

7. Bautista J, Ehsan M, Normandin E, Zuwallack R, Lahiri B. Physiologic responses during the six minute walk test in obese and non-obese COPD patients. Respir Med. 2011;105:1189-94.

8. O'Donnell DE, Deesomchok A, Lam YM, Guenette JA, Amornputtisathaporn $N$, Forkert L, et al. Effects of Body Mass Index on Static Lung Volumes in Patients with Airway Obstruction. Chest. 2011;140:461-8.

9. van den Borst B, Gosker HR, Koster A, Yu B, Kritchevsky SB, Liu Y, et al. The influence of abdominal visceral fat on inflammatory pathways and mortality risk in obstructive lung disease. Am J Clin Nutr. 2012;96:516-26.

10. Rutten EP, Breyer MK, Spruit MA, Hofstra T, van Melick PP, Schols AM, et al. Abdominal fat mass contributes to the systemic inflammation in chronic obstructive pulmonary disease. Clinical nutrition (Edinburgh, Scotland). 2010; 29:756-60.

11. Vanfleteren LE, van Meerendonk AM, Franssen FM, Wouters EF, Mottaghy FM, van Kroonenburgh MJ, et al. A possible link between increased metabolic activity of fat tissue and aortic wall inflammation in subjects with COPD. A retrospective 18 F-FDG-PET/CT pilot study. Respir Med. 2014;108:883-90.

12. Kaul S, Rothney MP, Peters DM, Wacker WK, Davis CE, Shapiro MD, et al. Dual-energy X-ray absorptiometry for quantification of visceral fat. Obesity (Silver Spring, Md). 2012;20:1313-8.

13. Bazzocchi A, Diano D, Ponti F, Salizzoni E, Albisinni U, Marchesini G, et al. A 360degree overview of body composition in healthy people: relationships among anthropometry, ultrasonography, and dual-energy $x$-ray absorptiometry. Nutrition (Burbank, Los Angeles County, Calif). 2014;30:696-701.

14. Spruit MA, Vanderhoven-Augustin I, Janssen PP, Wouters EF. Integration of pulmonary rehabilitation in COPD. Lancet (London, England). 2008;371:12-3.

15. Casanova C, Cote C, de Torres JP, Aguirre-Jaime A, Marin JM, Pinto-Plata V, et al. Inspiratory-to-total lung capacity ratio predicts mortality in patients with chronic obstructive pulmonary disease. Am J Respir Crit Care Med. 2005;171:591-7.

16. O'Donnell DE. Hyperinflation, dyspnea, and exercise intolerance in chronic obstructive pulmonary disease. Proc Am Thorac Soc. 2006;3:180-4.

17. Clausen $\mathrm{L}$, Coates AL, Quanjer PH. Measurement of lung volumes in humans: review and recommendations from an ATS/ERS workshop. Eur Respir J. 1997;10:1205-6.

18. Spruit MA, Augustin IM, Vanfleteren L, Janssen DJ, Gaffron S, Pennings HJ, et al. Differential response to pulmonary rehabilitation in COPD: multidimensional profiling. Eur Respir J. 2015;46:1625-35.

19. Furutate R, Ishii T, Wakabayashi R, Motegi T, Yamada K, Gemma A, et al. Excessive visceral fat accumulation in advanced chronic obstructive pulmonary disease. Int J Chron Obstruct Pulmon Dis. 2011;6:423-30.

20. Borkan GA, Gerzof SG, Robbins AH, Hults DE, Silbert CK, Silbert JE. Assessment of abdominal fat content by computed tomography. Am J Clin Nutr. 1982;36:172-7.

21. Grauer WO, Moss AA, Cann CE, Goldberg HI. Quantification of body fat distribution in the abdomen using computed tomography. Am J Clin Nutr. 1984:39:631-7

22. Sjostrom L, Kvist H, Cederblad A, Tylen U. Determination of total adipose tissue and body fat in women by computed tomography, $40 \mathrm{~K}$, and tritium. Am J Physiol. 1986;250:E736-45.

23. Kvist H, Chowdhury B, Grangard U, Tylen U, Sjostrom L. Total and visceral adipose-tissue volumes derived from measurements with computed tomography in adult men and women: predictive equations. Am J Clin Nutr. 1988;48:1351-61.
24. Maurovich-Horvat P, Massaro J, Fox CS, Moselewski F, O'Donnell CJ, Hoffmann $U$. Comparison of anthropometric, area- and volume-based assessment of abdominal subcutaneous and visceral adipose tissue volumes using multidetector computed tomography. Int J Obes (Lond). 2007;31:500-6.

25. Liou TH, Chan WP, Pan LC, Lin PW, Chou P, Chen CH. Fully automated large-scale assessment of visceral and subcutaneous abdominal adipose tissue by magnetic resonance imaging. Int J Obes (2005). 2006;30: 844-52.

26. Kullberg J, Ahlstrom $\mathrm{H}$, Johansson L, Frimmel H. Automated and reproducible segmentation of visceral and subcutaneous adipose tissue from abdominal MRI. Int J Obes (2005). 2007;31:1806-17.

27. Mazess RB, Peppler WW, Gibbons M. Total body composition by dual-photon (153Gd) absorptiometry. Am J Clin Nutr. 1984;40:834-9.

28. Gotfredsen A, Jensen J, Borg J, Christiansen C. Measurement of lean body mass and total body fat using dual photon absorptiometry. Metab Clin Exp. 1986;35:88-93.

29. Heymsfield SB, Wang J, Heshka S, Kehayias JJ, Pierson RN. Dual-photon absorptiometry: comparison of bone mineral and soft tissue mass measurements in vivo with established methods. Am J Clin Nutr. 1989;49:1283-9.

30. Mazess RB, Barden HS, Bisek JP, Hanson J. Dual-energy x-ray absorptiometry for total-body and regional bone-mineral and soft-tissue composition. Am J Clin Nutr. 1990:51:1106-12.

31. O'Donnell DE, Deesomchok A, Lam YM, Guenette JA, Amornputtisathaporn $\mathrm{N}$, Forkert $\mathrm{L}$, et al. Effects of BMI on static lung volumes in patients with airway obstruction. Chest. 2011;140:461-8.

32. Salome CM, King GG, Berend N. Physiology of obesity and effects on lung function. J Appl Physiol (Bethesda, Md : 1985). 2010;108:206-11.

33. Licata G, Scaglione R, Barbagallo M, Parrinello G, Capuana G, Lipari R, et al. Effect of obesity on left ventricular function studied by radionuclide angiocardiography. Int J Obes (Lond). 1991;15:295-302.

34. Karason K, Wallentin I, Larsson B, Sjostrom L. Effects of obesity and weight loss on cardiac function and valvular performance. Obes Res. 1998;6:422-9.

35. Krotkiewski M, Bjorntorp P, Sjostrom L, Smith U. Impact of obesity on metabolism in men and women. Importance of regional adipose tissue distribution. J Clin Invest. 1983:72:1150-62.

36. Lapidus L, Bengtsson C, Larsson B, Pennert K, Rybo E, Sjostrom L. Distribution of adipose tissue and risk of cardiovascular disease and death: a 12 year follow up of participants in the population study of women in Gothenburg, Sweden. Br Med J (Clin Res Ed). 1984;289:1257-61.

37. Despres JP, Moorjani S, Ferland M, Tremblay A, Lupien PJ, Nadeau A, et al. Adipose tissue distribution and plasma lipoprotein levels in obese women. Importance of intra-abdominal fat. Arteriosclerosis (Dallas, Tex). 1989;9:203-10.

38. Janssen I, Katzmarzyk PT, Ross R. Waist circumference and not body mass index explains obesity-related health risk. Am J Clin Nutr. 2004;79:379-84.

39. Kuk JL, Katzmarzyk PT, Nichaman MZ, Church TS, Blair SN, Ross R. Visceral fat is an independent predictor of all-cause mortality in men. Obesity (Silver Spring, Md). 2006;14:336-41.

40. Poirier P, Despres JP. Waist circumference, visceral obesity, and cardiovascular risk. J Cardiopulm Rehabil. 2003;23:161-9.

41. Hayashi T, Boyko EJ, McNeely MJ, Leonetti DL, Kahn SE, Fujimoto WY. Minimum waist and visceral fat values for identifying Japanese Americans at risk for the metabolic syndrome. Diabetes Care. 2007;30:120-7.

\section{Submit your next manuscript to BioMed Central and we will help you at every step:}

- We accept pre-submission inquiries

- Our selector tool helps you to find the most relevant journal

- We provide round the clock customer support

- Convenient online submission

- Thorough peer review

- Inclusion in PubMed and all major indexing services

- Maximum visibility for your research

Submit your manuscript at www.biomedcentral.com/submit 